\title{
A study on relationship between service quality and customer satisfaction: An empirical evidence from Pakistan telecommunication industry
}

\author{
Muhammad Ishtiaq Ishaq ${ }^{\mathrm{a}^{*}}$
}

${ }^{a}$ Department of Management Science, Global Institute Lahore, Pakistan

\begin{tabular}{l}
\hline A R T I C L E I N F O \\
\hline Article history: \\
Received May 1, 2011 \\
Received in Revised form \\
June, 7, 2011 \\
Accepted 8 June 2011 \\
Available online \\
12 June 2011 \\
\hline Keywords: \\
Services quality \\
Customer Satisfaction \\
Telecommunication Industry \\
Pakistan
\end{tabular}

\section{A B S T R A C T}

\begin{abstract}
The purpose of this study is to determine the impact of service quality on the overall customer satisfaction in telecommunication industry of Pakistan. Survey questionnaires are used to collect the data from the postpaid users of different telecommunication service providers. Stepwise regression analysis is used to examine the research hypothesis. The results show that service quality has positive association with the overall customer satisfaction. This study is a unique approach, which describes the factors affecting customer's satisfaction. The findings of this research provide insights for the managers to develop and maintain the customer's desired service quality. Implications for marketing strategists and researchers are presented.
\end{abstract}

(C) 2011 Growing Science Ltd. All rights reserved.

\section{Introduction}

The speedy growth and cut-throat competition in service industries e.g., telecommunication industry in developed and developing countries made it significantly essential element for measuring and evaluating service quality (Brown \& Bitner, 2007). Today, service quality not only has become the rhetoric of each business but also it has taken distinguished position in every discourse. Without customer satisfaction and loyalty, no company can survive in today's competitive environment; similarly no organization can generate high sales without meeting the customer needs. Service quality plays a vital role in building a strong and ever lasting relationship between customers and organization and it is a two-way flow of value.

Numerous empirical studies conducted on service quality and customer satisfaction (Cronin \& Taylor, 1992; Spreng \& Mackoy, 1996; Jones \& Suh, 2000; Coyles \& Gokey, 2002; Ranaweera \& Prabhu, 2003; Choi et al., 2004), and predictor of the financial strength of the organization (Greising, 1994; Rust et al., 1995; Duncan \& Elliott, 2002; Duncan \& Elliott, 2004; Yasin et al., 2004; Wiele et al., 2002; Yeung et al., 2002). However, these studies were conducted in developed world like United State of America, United Kingdom and Japan, which show there is a lack of relevant literature in

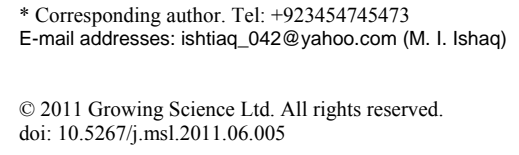


developing countries, including Pakistan, which has yet to be covered by research especially in telecommunication industry where very little attention has been devoted. It means the impact of service quality on customer satisfaction in the telecommunication sector has not received sufficient research in Pakistan. This study looks for the relationship between service quality and customer satisfaction in telecommunication industry of Pakistan, which is an attempt to fill the gap in literature and provides more empirical evidences on the effects of service quality on customer satisfaction.

Service quality can be defined as the delivery of superior and excellent service to the customers according to their expectations (Cronin \& Taylor, 1992; Oliver, 1993; Zeithaml et al., 1993; Santos, 2003). The three key features of service quality were outcome quality, physical service environment quality and interaction quality. Numerous researchers explained these three broad dimensions of renowned construct of service quality system called SERVQUAL. SERVQUAL has five dimensions: tangibles, reliability, responsiveness, empathy and assurance (Parasuraman et al., 1988). The first dimension (tangibles) has commenced with physical environment, the reliability corresponds with service outcome and the remaining three deals with interaction quality aspects. Service quality is precursor of the theory of customer satisfaction (Lee et al., 2000; Buttle, 1996; Zeithaml \& Bitner, 1996; Gotlieb et al., 1994) and the relationship between loyalty and service quality is intervened by satisfaction (Caruana, 2002; Fullerton \& Taylor, 2002).

Recently, there has been more attention on conceptualization and measuring service quality in telecommunication sector since there is a sharp increase in penetration rates around the world. Van der Wal et al. (2002) used SERVQUAL measures to determine the service quality in telecommunication sector in South Africa and confirmed that this instrument can be used to assess service quality in that industry. Johnson and Sirikit (2002) also employed SERVQUAL instrument to investigate service quality perceptions in the Thai telecommunication industry and showed that these measures is suggested for process-driven service provider companies such as telecommunications, retaining, health, banking, etc. Another flow of researches focused on developing service quality measurement tools by targeting mobile telephony sector specifically (Aydin \& Ozer, 2005; Gerpott et al., 2001; Kim et al., 2004; Lee et al., 2001; Lim et al., 2006). In the study of Choi et al. (2007) the mobile telephony quality measuring dimensions recognized the work categorized into coverage of network, mobile device, billing system, convenience, value-added services, and price structure. The causal relationship between service quality and customer satisfaction is verified in various sectors such as telecommunication industry and confirms the positive relationship of service quality on satisfaction (Kim et al., 2004; Lee et al., 2001; Lim et al., 2006).

For more than two decades, customer satisfaction has been intensively the subject of discussion among the area of market and consumer research. Recently, customer satisfaction has reaped new attention within the framework of the paradigm changed from transactional to relationship marketing (Martin et al., 2002), which refers towards the marketing activities associated with establishing, developing, and maintaining successful relational exchanges (Yi \& La, 2004). Customer satisfaction is emotional state, which leads to an overall, global attitude of quality (Dabholkar, 1993), which is only based on some kind of inner expectation standard. Customer satisfaction can be measured on a single-item scale or as multi-item scale assessing the satisfaction level for each factor of the service. For instance, Cronin and Taylor (1992) measured customer satisfaction on one-item scale covers the overall feelings towards an organization while 6-item construct was used by Anderson and Srinivasan (2003) for measuring customer satisfaction for each service quality of the organization.

Customer satisfaction is also considered as fundamental determinant of customer loyalty. Satisfaction improves repeat purchases and produces positive word of mouth (Reichheld \& Sasser, 1990; Wirtz, 2003). The same results reported in the telecommunications services literature, where satisfaction had emerged as strong predictor of customer loyalty. Gerpott et al. (2001) in German cellular telecommunications, Kim et al. (2004) in Korea and Lee et al. (2001) in France highlighted the causal 
relationship of customer satisfaction and loyalty. Commonly, two general conceptualizations of satisfaction exist, namely, transaction-specific satisfaction and cumulative satisfaction (Jones \& Suh, 2000; Yi \& La, 2004). Transaction-specific satisfaction is the evaluation of his/her experience about particular service encounter by the customer (Boshoff \& Gray, 2004) and cumulative satisfaction is associated with the overall evaluation of customers of the consumption experience to date (Cook, 2008).

\section{Research design}

Survey questionnaires were used to collect the data from the respondents. Following research design was utilized to test the hypotheses presented hereunder;

2.1 Research Hypothesis: There is a positive relationship between service quality and customer satisfaction.

\subsubsection{Sampling \& Procedure}

There are two types of users exist in telecommunication sector of Pakistan e.g. prepaid and postpaid. The key respondents of this research are the postpaid users because they are the key clients of telecommunication industry and usually use one network. The questionnaires were distributed to the students of Executive MBA studying in government college university, University of Punjab, COMSATS Institute of Information Technology and University of Engineering and Technology in February 2010. From multi-follow ups, two hundred and eighty five (285) questionnaires were returned with the response rate of $81 \%$, which is highly appreciable. Stepwise regression analysis was employed to determine the service quality impact on the satisfaction of the customers. In this study, all six determinants of service quality were treated as independent variables whereas overall customer satisfaction was served as dependent variables.

\subsection{Survey Instrument}

Following instruments were used:

(1) Service quality: Choi et al. (2007) summarized and classified the quality factors recognized in research of telecommunication sector. Therefore, service quality is conceptualized as:

$>$ Network (two items): Clarity of voice and the area coverage are factors according to Kim et al. (2004) and Lim et al. (2006).

$>$ Value-added services (three items): As value-added services can be considered as intangible objects like SMS and MMS, WAP, GPRS, news, ringtones etc (Kim et al., 2004).

$>$ Mobile devices (three items): This variable was measured by the variety, quality, and design of different mobile devices, which were adapted from Kim et al. (2004).

$>$ Customer service (four items): These dimensions estimate the success of problem resolution, the courtesy offered by customer service representatives, help provided by service/call-centers and the provision of consistent advice. All items adopted from Lim et al. (2006).

$>$ Pricing structure (three items): Reasonable prices, variety in pricing schemes and the extent of liberty to choose pricing scheme, this measured was used by Kim et al. (2004).

$>$ Billing system (three items): This dimension includes the provision of correct billing, ease in resolving the billing issues and the speed of resolving the billing problem, as suggested by Lim et al. (2006).

(2) Customer satisfaction: Single item scale was used to determine the overall customer satisfaction. 


\section{Analysis \& Interpretations}

Respondent sample, descriptive statistics and stepwise regression analysis were used to interpret this section. Table 1 shows the demographic characteristics of the respondents of five different telecommunication service providers. Male respondents were $60 \%$ and females accounted for $40 \%$. For age, 24 percent participants were below 30 years, 32 percent were 31-39 years, 26 percent were 40-49 years and 18 percent were more than 50 years of age. As for service users of the companies, $29 \%$ using postpaid services of Mobilink, 24\% Telenor, 23\%, Warid, $14 \%$ Ufone and 10\% are currently using the postpaid services of Zong. About 29 percent were using the services up to 1 year, 39 percent used 2-3 years, and 32 percent used their current services for more than 3 years.

\section{Table 1}

Demographics Profile

\begin{tabular}{|c|c|c|c|c|c|}
\hline Characteristics & Frequency & Percentage (\%) & Characteristics & Frequency & Percentage $(\%)$ \\
\hline $\begin{array}{l}\text { Gender: } \\
\text { Male } \\
\text { Female }\end{array}$ & $\begin{array}{l}172 \\
113\end{array}$ & $\begin{array}{l}60 \\
40\end{array}$ & $\begin{array}{l}\text { Age: } \\
\text { Below } 30 \\
31-39 \text { years } \\
40-49 \text { years } \\
\text { Above } 50 \text { years }\end{array}$ & $\begin{array}{l}67 \\
91 \\
73 \\
54\end{array}$ & $\begin{array}{l}24 \\
32 \\
26 \\
18\end{array}$ \\
\hline $\begin{array}{l}\text { Name of Service Users: } \\
\text { Mobilink } \\
\text { Telenor } \\
\text { Warid } \\
\text { Ufone } \\
\text { Zong }\end{array}$ & $\begin{array}{l}81 \\
74 \\
65 \\
39 \\
26\end{array}$ & $\begin{array}{l}29 \\
24 \\
23 \\
14 \\
10\end{array}$ & $\begin{array}{l}\text { Service-Users Since: } \\
\text { Up to } 1 \text { year } \\
2-3 \text { years } \\
\text { More than } 3 \text { years }\end{array}$ & $\begin{array}{l}84 \\
108 \\
93\end{array}$ & $\begin{array}{l}29 \\
39 \\
32\end{array}$ \\
\hline
\end{tabular}

Table 2 shows the mean and standard deviation (descriptive statistics) of different variables of service quality and customer satisfaction.

Table 2

Descriptive Statistics ( $\mathrm{N}=285)$

\begin{tabular}{lll}
\hline Variables & Mean & Std. Deviation \\
\hline Network & 3.81 & 0.78 \\
Value-added Services & 3.60 & 0.67 \\
Mobile Device & 3.52 & 0.74 \\
Customer Service & 4.04 & 0.82 \\
Pricing Structure & 4.14 & 0.75 \\
Billing System & 3.98 & 0.81 \\
Customer Satisfaction & 4.02 & 0.81 \\
\hline
\end{tabular}

Table 3 shows the Pearson inter-item correlations of service quality dimensions and customer satisfaction. All the items are moderately correlated with each other where the level of significant is 0.01 and there is no co-linearity so all the variables are fit for regression analysis.

Table 3

Pearson Correlation Matrix

\begin{tabular}{llllllll}
\hline & NTW & VAS & MD & CS & PS & BS & CSat. \\
\hline NTW & 1.00 & & & & & \\
VAS & $0.37^{*}$ & 1.00 & & & & \\
MD & $0.31^{*}$ & $0.32^{*}$ & 1.00 & & & \\
CS & $0.40^{*}$ & $0.30^{*}$ & $0.33^{*}$ & 1.00 & & & \\
PS & $0.42^{*}$ & $0.33^{*}$ & $0.37^{*}$ & $0.32^{*}$ & 1.00 & & \\
BS & $0.32^{*}$ & $0.37^{*}$ & $0.35^{*}$ & $0.30^{*}$ & $0.31^{*}$ & 1.00 & $0.37^{*}$ \\
CSat. & $0.39^{*}$ & $0.36^{*}$ & $0.31^{*}$ & $0.40^{*}$ & $0.33^{*}$ & 1.00 \\
\hline
\end{tabular}

NTW $=$ Network, VAS $=$ Value-added Services, $M D=$ Mobile Device, $C S=$ Customer Service, $P S=$ Pricing System, BS $=$ Billing System, CSat. $=$ Customer Satisfaction

* Significant at 0 .01 level: One-tailed, 
Table 4 shows stepwise regression analysis, which reflects that about $59 \%$ variance (adjusted $\mathrm{R}^{2}=$ .58) in customer satisfaction was explained by the model, which consists of value added service, customer service and pricing system. This results was consistent with the study research hypothesis that service quality have impact on customer satisfaction

Table 4

Model Summary (Dependent Variable: Overall Customer Satisfaction)

\begin{tabular}{llllllll}
\hline Model & $\mathrm{R}$ & $\mathrm{R}^{2}$ & Adjusted $\mathrm{R}^{2}$ & $\begin{array}{l}\text { Std. Error of } \\
\text { Estimate }\end{array}$ & $\begin{array}{l}\mathrm{R}^{2} \\
\text { Change }\end{array}$ & $\begin{array}{l}\mathrm{F} \\
\text { Change }\end{array}$ & $\begin{array}{l}\text { Durbin- } \\
\text { Watson }\end{array}$ \\
\hline 1 & $0.63^{\mathrm{a}}$ & .39 & .38 & 0.41 & 0.39 & $53.32^{*}$ & \\
2 & $0.70^{\mathrm{b}}$ & .48 & .047 & 0.38 & 0.09 & $14.50^{*}$ & \\
3 & $0.74^{\mathrm{c}}$ & .59 & .58 & 0.37 & 0.11 & $12.63^{*}$ & 1.78 \\
\hline c. Predictors: (constant), Value-added Service, Customer Service and Pricing System & & &
\end{tabular}

ANOVA results (Table 5) indicate the predictive strength $(F 3,82=33.35, \mathrm{p}<.000)$ of the model to explain variance in customer satisfaction.

Table 5

ANOVA (Dependent Variable: Overall Customer Satisfaction)

\begin{tabular}{clllll}
\hline Model & Sum of Squares & Df & Mean Square & F & Sig. \\
\hline Regression & 12.69 & 3 & 4.22 & 33.35 & $.000^{\mathrm{g}}$ \\
Residual & 1.28 & 82 & 0.16 & \\
\multicolumn{2}{l}{ Total } & 23.97 & 85 & & \\
\hline \multicolumn{2}{l}{ c. Predictors: (constant), Value-added Service, Customer Service and Pricing System } & &
\end{tabular}

Table 6

Coefficients $^{\mathrm{a}}$

\begin{tabular}{|c|c|c|c|c|c|c|c|}
\hline \multirow[b]{3}{*}{ Model } & \multirow{2}{*}{\multicolumn{2}{|c|}{$\begin{array}{l}\text { Unstandardized } \\
\text { Coefficients }\end{array}$}} & \multirow{3}{*}{$\begin{array}{l}\text { Standardized } \\
\text { Coefficients } \\
\text { Beta }\end{array}$} & \multirow{3}{*}{$\mathrm{t}$} & \multirow{3}{*}{ Sig. } & \multicolumn{2}{|c|}{ Collinearity Statistics } \\
\hline & & & & & & & \\
\hline & $\mathrm{B}$ & Std. Error & & & & Tolerance & VIF \\
\hline (Constant) & 2.03 & .38 & & 5.48 & .000 & & \\
\hline Value Added Service & .28 & .30 & .31 & 3.06 & .000 & .73 & 1.70 \\
\hline Customer Service & .37 & .40 & -.32 & 4.77 & .000 & .92 & 1.33 \\
\hline Pricing System & .23 & .32 & .13 & 3.55 & .019 & .66 & 1.45 \\
\hline
\end{tabular}

a. Dependent Variable: behavioral responses

The beta coefficients in Table 6 show the impact of service quality on customer satisfaction such as value-added services, customer service and pricing value. As the table shows, value added service (b $=.28, \mathrm{t}=3.06, \mathrm{p}<0.000)$, customer service $(\mathrm{b}=0.37, \mathrm{t}=4.77, \mathrm{p}<0.000)$ and pricing system $(\mathrm{b}=.23, \mathrm{t}=$ $3.55, \mathrm{p}<0.05)$ have positive relationship with the customer satisfaction in telecommunication industry of Pakistan.

This pointed out that the users of mobile telephony pay more attention to core service issues, such as customer care, value added service and pricing schemes, than advanced phone devices. The results of this study largely agree with other researchers found in literature. Customer support was found to be an important customer satisfaction predictor by Kim et al. (2004) and there was no evidence, which explain the effect of the dimension of mobile devices on customer satisfaction. Lim et al. (2006) research proved that pricing plans have effect on customer satisfaction. On the other hand, previous studies also confirmed positive effect of value-added services on satisfaction (Kim et al., 2004; Lim et al., 2006). In addition, Lee et al. (2001) found that heavy-users reveal strong affiliation with valueadded services, which ultimately increased their satisfaction. 


\section{Conclusions and recommendations}

The results of this study showed that service quality has contributed in overall customer satisfaction. This research found that three dimensions of service quality (value added service, customer service and pricing system) out of the six instrument have significant positive effects on customer satisfaction. These findings have practical utilization for the management of telecommunication companies to improve and implement best practices, which will lead customer satisfaction loyalty. Findings showed that the reasonable prices, variety in pricing schemes and degree of freedom to choose a scheme and provision of accurate billing, ease and speed of resolving billing issues require great attention. There are some limitations of this research. Due to non-probability sampling, results cannot be generalized to whole population and future research could look into the possible mediation

role of switching costs on the link between satisfaction and service quality. Last but not the least, this research conducted in one industry and in one geographical boundary.

\section{References}

Anderson, R.E., \& Srinivasan, S.S. (2003). E-satisfaction and e-loyalty: a contingency framework. Psychology and Marketing, 20(2), 123-38.

Aydin, S., \& Ozer, G. (2005). The analysis of antecedents of customer loyalty in the Turkish mobile telecommunication market. European Journal of Marketing, 39(7/8), 910-25.

Boshoff, C., \& Gray, B. (2004). The Relationships between Service Quality, Customer Satisfaction and Buying Intentions in the Private Hospital Industry. South African Journal of Business Management, 35(4), 27-37.

Brady, M. K., Cronin Jr., J. J., \& Brand, R. R. (2002). Performance-only measurement of service quality: A replication and extension. Journal of Business Research, 55(1), 17-31.

Brown, S.W., \& Bitner, M.J. (2007). Mandating a service revolution for marketing, in Lusch, R.F. and Vargo, S.L. (Eds), The Service-Dominant Logic of Marketing: Dialog, Debate and Directions, M.E. Sharpe, Armonk, NY.

Buttle, F. (1996). Relationship marketing. In: Buttle, F. (Ed.), Relationship Marketing: Theory and Practice. Paul Chapman Publishing, London.

Caruana, A. (2002). Service loyalty: The effects of service quality and the mediating role of customer satisfaction. European Journal of Marketing, 36 (7/8), 811-828.

Choi, C., Kim, C., Sung, N., \& Park, Y. (2007). Evaluating the quality of service in mobile business based on fuzzy set theory. Fourth International Conference on Fuzzy Systems and Knowledge Discovery, Haiku, China, August 2007, 483-487.

Choi, K. S., Cho, W. H., Lee, S. H., Lee, H. J., \& Kim, C. K. (2004). The Relationships among Quality, Value, Satisfaction and Behavioral Intention in Health Care Provider Choice: A South Korean Study. Journal of Business Research, 57(8), 913-921.

Cook, S. (2008). Customer Care Excellence: How to Create an Effective Customer Focus, London: Kogan Page.

Coyles, S., \& Gokey, T. C. (2002). Customer Retention is not Enough. The McKinsey Quarterly. 2, 80-89.

Cronin, J. J., \& Taylor, S. A. (1992). Measuring Service Quality: A Reexamination and Extension. Journal of Marketing, 56(3), 55-68.

Dabholkar, P., (1993). A Measurement of Service Quality for Retail Stores: Scale Development and Validation, Journal of the Academy of Marketing Science, 24(1), 3-16.

Duncan, E., \& Elliott, G. (2002). Customer service quality and financial performance among Australian retail financial institutions. Journal of Financial Services Marketing, 7(1), 25-41.

Duncan, E., \& Elliott, G. (2004). Efficiency, customer service and financial performance among Australian financial institutions. The International Journal of Bank Marketing, 22(5), 319-42. 
Fullerton, G., \& Taylor, S. (2002). Mediating, interactive, and non-linear effects in service quality and satisfaction with services research. Canadian Journal of Administrative Sciences, 19(2), 12436.

Gerpott, T.J., Rams, W., \& Schindler, A. (2001). Customer retention, loyalty and satisfaction in the German mobile cellular telecommunications market. Telecommunications Policy, 25(4), 249-69.

Gotlieb, J.B., Grewal, D., \& Brown, S.W. (1994). Consumer satisfaction and perceived quality: complementary or divergent constructs?. Journal of Applied Psychology, 79(6), 875-885.

Greising, D. (1994). Quality: how to make it pay. Business Week, 8 August, 54-9.

Johnson, W.C., \& Sirikit, A. (2002). Service quality in the Thai telecommunication industry: a tool for achieving a sustainable competitive advantage. Management Decision, 40(7), 693-701.

Jones, M. A., \& Suh, J. (2000). Transaction-Specific Satisfaction and Overall Satisfaction: An Empirical Analysis. Journal of Services Marketing, 14(2), 147-159.

Kim, M.K., Park, M.C., \& Jeong, D.H. (2004). The effects of customer satisfaction and switching barrier on customer loyalty in Korean mobile telecommunication services. Telecommunications Policy, 28(2), 145-59.

Kotler, P. (2003). Marketing Management, Prentice-Hall, Englewood Cliffs, NJ.

Lee, H., Lee, Y., \& Yoou, D. (2000). The determinants of perceived service quality and its relationship with satisfaction. Journal of Service Marketing, 14(3), 217-231.

Lee-Kelley, L., Gilbert, D. \& Mannicom, R. (2003). How e-CRM can enhance customer loyalty. Marketing Intelligence \& Planning, 21(4), 239-48.

Lim, H., Widdows, R., \& Park, J. (2006). M-loyalty: winning strategies for mobile carriers. Journal of Consumer Marketing, 23(4), 208-18.

Martin C., Adrian P., \& David B. (2002). Relationship marketing: Creating Customer Value, Burlington: Elsevier Butterworth-Heinemann.

Oliver, R. L. (1981). Measurement and Evaluation of Satisfaction Processes in Retail Settings. Journal of Retailing, 57(3), 25-48.

Oliver, R. L. (1993). Cognitive, Affective, and Attribute Bases of the Satisfaction Response. Journal of Consumer Research, 20, 418-430.

Parasuraman, A., Zeithaml, V.A., \& Berry, L.L. (1988). SERVQUAL: a multiple-item scale for measuring consumer perception of service quality. Journal of Retailing, 64, 12-40.

Ranaweera, C., \& Prabhu, J. (2003). On the Relative Importance of Customer Satisfaction and Trust as Determinants of Customer Retention and Positive Word of Mouth. Journal of Targeting, Measurement and Analysis for Marketing, 12(1), 82-90.

Reichheld, F.F., \& Sasser, W.E. (1990). Zero defections: quality comes to services. Harvard Business Review, 68(5), 105-11.

Rust, R. T., \& Oliver, R. L. (1994). Service quality: New directions in theory and practice. London: Sage.

Rust, R.T., Zahorik, A.J., \& Keiningham, T.L. (1995). Return on quality (ROQ): making service quality financially accountable. Journal of Marketing, 59, 58-70.

Santos, J. (2003). E-service quality: a model of virtual service quality dimensions. Managing Service Quality, 13(3), 233-46.

Spreng, R. A., \& Mackoy, R. D. (1996). An Empirical Examination of a Model of Perceived Service Quality and Satisfaction. Journal of Retailing, 72(2), 201-214.

Van der Wal, R.W.E., Pampallis, A., \& Bond, C. (2002). Service quality in a cellular telecommunications company: a South African experience. Managing Service Quality, 12(5), 32335.

Wiele, T., Boselie, P., \& Hesselink, M. (2002). Empirical evidence for the relationship between customer satisfaction and business performance. Managing Service Quality, 12(3), 184-193.

Wirtz, J. (2003). Halo in customer satisfaction measures. International Journal of Service Industry Management, 14(1), 96-119. 
Yasin, M., Correia, E., \& Lisboa, J. (2004). The profitability of customer-targeted quality improvement efforts: an empirical examination. The TQM Magazine, 16(1), 45-49.

Yeung, M., Ging, L., \& Ennew, C. (2002). Customer satisfaction and profitability: a reappraisal of the nature of the relationship. Journal of Targeting, Measurement and Analysis for Marketing, 11(1), 24-33.

Yi, Y. J., \& La, S. N. (2004). What Influences the Relationship between Customer Satisfaction and Repurchase Intention? Investigating the Effect of Adjusted Expectations and Customer Loyalty. Psychology and Marketing, 21(5), 351-373.

Zeithaml, V. A., Berry, L. L., \& Parasuraman, A. (1993). Delivering quality service: Balancing customer perceptions and expectations. New York: New York Free Press.

Zeithaml, V.A., \& Bitner, M.J. (1996). Service Marketing. McGraw-Hill, NewYork. 